Philosophes dans la tourmente

Élisabeth Roudinesco

Paris: Fayard, 2005, 275 p.

\title{
Élisabeth Roudinesco revisita os filósofos da tempestade
}

\section{Mario Eduardo Costa Pereira}

Lançado na França no final de 2005, Philosophes dans la tourmente, de Élisabeth Roudinesco, constitui um apaixonante resgate do pensamento filosófico francês da segunda metade do século $X X$, justamente em um momento em que o mundo contemporâneo se mostra tão pouco afeito a paixões ou a contestações radicais de suas certezas cotidianas. Politicamente correto, conservador e bem-comportado, o homem de hoje aprendeu que precisa “fazer a lição de casa”, preparar-se individualmente para a feroz competição do mercado e a aceitar a ordem reinante como um fato consumado. Acreditamos na democracia, na ciência experimental e na implacável autonomia da forma capitalista de organizar as trocas humanas. Não é, portanto, à toa que o foco do livro seja a França do crepúsculo do milênio: quantas esperanças revolucionárias, quanto inconformismo, quantas promessas de ruptura com as ideologias opressoras que conduziram à guerra, aos preconceitos versão pós-moderna e ao escandaloso depauperamento de inúmeros povos e camadas sociais. Maio de 1968 talvez tenha sido o apogeu de um tempo em que a utopia ainda parecia fazer sentido em nossas formas de estar no mundo. 
Roudinesco escolhe, assim, seis filósofos franceses, díspares por vezes em pontos fundamentais de seus pensamentos e teorias, mas que possuíam em comum o fato de recusarem ser "os servidores de uma normalização do homem”. Propunham no bojo de sua obra uma filosofia do engajamento político, um questionamento radical sobre "a natureza do sujeito", bem como um debate com a concepção freudiana do inconsciente. Conheceram em vida, cada qual à sua maneira, o fascínio que os rebeldes provocam e a rejeição visceral que despertam por constituírem uma ameaça a nossas formas habituais de conceber o mundo.

Nada mais natural, pois, que o primeiro personagem retratado seja Georges Canguilhem, autor de $O$ normal e o patológico, livro que justamente interroga uma das noções mais caras à pós-modernidade: a normalidade lida através da razão médico-biológica e suas pretensas garantias científicas, e o estatuto correlativo da anomalia. Apresentado por um subtítulo ao mesmo tempo épico e romântico - "uma filosofia do heroísmo" - Canguilhem constitui a figura emblemática do grande mestre, rigoroso em seu ofício filosófico e profundamente implicado com as conseqüências éticas de um percurso intelectual. Ele é reconhecido como uma espécie de matriz intelectual e moral à base de toda uma geração de pensadores franceses que viria contribuir para a instalação do espírito rebelde e inconformista da Europa pós-guerra. Ao estabelecer uma linha de demarcação das grandes correntes de pensamento na França de seu tempo, Foucault incluía Canguilhem entre os filósofos “do saber, da racionalidade e do conceito”, juntamente com Cavaillès e Koyré, em contraste com os filósofos da experiência, do sentido e do sujeito, tais como Merleau-Ponty e Sartre.

Pacifista por convicção e por natureza, Canguilhem soube "escolher seu campo" no momento em que eclode a guerra, engajando-se decididamente no apoio à Resistência e às atividades do movimento de Liberação. Situa-se aí a “filosofia do heroísmo” de que falava Élisabeth Roudinesco: “que soube associar a um só tempo e em um mesmo movimento, a mais alta reflexão conceitual e o engajamento político mais vigoroso”.

Jean-Paul Sartre, Michel Foucault, Louis Althusser, Gilles Deleuze e Jacques Derrida são os cinco filósofos que completam o vasto painel da inquietude intelectual francesa do século XX desenhado em Philosophes dans la tourmente.

O autor de A náusea é apresentado, com todas as nuanças e diferentes matizes, como o ícone mesmo de uma filosofia do engajamento. Nessa perspectiva, a obra sartreana remeteria todo ato de resistência, chegando mesmo à morte heróica, não a uma decisão consciente psicologicamente compreensível, mas "a uma confrontação com o horror de um possível aniquilamento de si mesmo”. Ou seja, diante de certas encruzilhadas existenciais decisivas, nas quais a tomada de posição implica a constituição do próprio sentido para a vida, 
renunciar à coerência consigo próprio equivale a esvaziar a consistência mesma do existir.

Foucault, observado sobretudo a partir dos efeitos produzidos por sua História da loucura, constitui uma espécie de protótipo do pensador ao mesmo tempo odiado e idealizado pela contundência de suas propostas e pela dimensão escandalosa de sua face pública. Retomando o ímpeto das obras de Nietzsche e de Bataille, Foucault fez “surgir da razão ocidental esta parte 'maldita' irredutível a toda forma de controle discursivo”. A loucura desnaturalizada, arrancada do discurso médico-psiquiátrico e inserida nos contextos ideológicos e de poder próprios a cada tempo, tem na obra foucaultiana a força de denúncia da contingência de nossas certezas quanto à organização simbólica do mundo, descortinando ao homem contemporâneo a ameaça totalitária de seus sistemas de compreensão da existência, que o liberam da angústia ao preço de profunda alienação.

A “cena do assassinato”, tomada como ponto de articulação entre o homem e a obra, forma o eixo de debate sobre as interrogações filosóficas colocadas por Louis Althusser. Eminente teórico do marxismo, ligado à “filosofia do conceito”, Althusser foi também membro do Partido Comunista Francês e militante engajado de um projeto revolucionário. O crime de morte que cometeu contra sua esposa, em novembro de 1980, marcaria definitivamente toda leitura possível de seu pensamento. Tendo sido declarado pela justiça como não responsável por seu ato em função deste ter sido executado em um episódio de melancolia aguda, o filósofo experimenta tal condição como a de ser reconhecido, em função de sua loucura, “como um não-sujeito de direito”. Dessa forma, obtinha a liberdade (ou mesmo a sobrevivência física, uma vez que à época a pena de morte ainda vigorava na França) à custa de se ver privado de responder simbolicamente, junto ao laço social, sobre a sua implicação subjetiva efetiva em seu ato extremo. Colocava-se, dessa forma, e de maneira trágica, a encarnação mesma em sua existência dos efeitos de poder do discurso dos especialistas, os quais são socialmente reconhecidos como competentes para deliberar sobre o sentido último dos processos íntimos de um sujeito.

Gilles Deleuze, por sua vez, tem como pólo de interlocução o impacto causado por seu $O$ anti-Édipo, publicado em 1972, escrito em colaboração com Felix Guattari. Esse livro, expressão de uma antipsiquiatria à francesa, teve imediato impacto mundial. Nele era denunciada a concepção freudiana segundo a qual o principal organizador dos destinos da libido seria o complexo de Édipo. Os autores criticavam o caráter normalizante e conservador de uma psicanálise que se dá por tarefa reinscrever o sujeito nos estreitos parâmetros de um quadro familiar tradicional. Para eles, era necessário conceber o desejo e sua circulação 
da forma mais aberta e livre possível. Tratava-se, antes de tudo, de uma postura teórica com incidências clínicas revolucionárias: destituição do caráter de matriz simbólica absoluta atribuída ao Édipo e liberação socialmente compartilhada dos fluxos desejantes.

Por fim, e não menos impactante, a autora realiza uma emocionante homenagem a Jacques Derrida a partir da atitude deste com esse momento crucial em que o amigo sobrevivente deve realizar o adeus ao amigo morto. Retomando um dos últimos livros publicados por Derrida, Chaque fois unique, la fin $d u$ monde, em que o filósofo reúne os elogios fúnebres que houvera feito a amigos e colegas - como Roland Barthes, Paul de Man, Michel Foucault, Louis Althusser, Gilles Deleuze, Emmanuel Lévinas e Maurice Blanchot - Élisabeth Roudinesco trata das questões relativas à separação, à finitude e à morte tal como essas são abordadas no pensamento e na vida do teórico da desconstrução. Aborda-se, assim, "a lei inflexível e fatal: de dois amigos, um verá o outro morrer”.

Esse final dá ao livro um tom um tanto melancólico; a própria autora faz o elogio fúnebre do amigo desaparecido. O mesmo que, por sua vez, havia retratado a dor intraduzível da despedida de seus companheiros de história intelectual e de vida. Uma geração de pensadores rebeldes que para permanecer coerente consigo mesma precisou atravessar a tormenta. Trata-se de um elogio fúnebre desse tempo e de suas esperanças? Ao mesmo tempo, o impacto desse livro faz revelar ao leitor - em si mesmo - sua própria inconformidade submergida, sua insurreição abafada. Se os filósofos da tormenta nos tocam é por que seu legado, e nós mesmos, ainda estamos vivos e, ao menos no íntimo, ainda resistimos com rebeldia a nos deixarmos traduzir integralmente pelos discursos totalitários do Outro. 